\title{
EFFECT OF DIFFERENT N FORMS AND CONCENTRATIONS ON OLIVE SEEDLINGS GROWTH
}

\author{
J.L. García, J. Liñán, R. Sarmiento and A. Troncoso. \\ Instituto de Recursos Naturales y Agrobiología (CSIC). \\ P.O. Box 1052,41080 Sevilla, Spain.
}

Keywords: olive, seedlings, greenhouse, nitrogen, nutrition, growth

\begin{abstract}
The effect of different $\mathrm{N}$ forms on the growth of olive seedlings in the greenhouse was studied. $\mathrm{KNO}_{3}, \mathrm{NH}_{4} \mathrm{NO}_{3}$ and $\left(\mathrm{NH}_{4}\right)_{2} \mathrm{SO}_{4}$ at different concentrations, as well as two types of substrates, sterile sand and a sand-peat mixture (1:1), were tested. In sterile sand, with $\mathrm{N}$ concentrations higher than $5 \mathrm{mM}$, serious damage was observed in the plants, so concentrations of 3,4 and $5 \mathrm{mM}$ of $\mathrm{N}$ were used for each $\mathrm{N}$ salt. $\mathrm{N}-\mathrm{NH}_{4}$ treatments resulted in a significantly higher growth compared to $\mathrm{KNO}_{3}$ treatment. Using the peatsand substratc and the $\mathrm{N}$ concentrations described above, seedling growth was higher than in sterile sand, but no differences among treatments were observed. However, the peat:sand substrate allowed application of higher $\mathrm{N}$ concentrations and using $\mathrm{NH}_{4} \mathrm{NO}_{3}$ differences in growth were obtained, reaching the best results with $14-28 \mathrm{mM}$.
\end{abstract}

\section{Introduction}

One of the main problems for the olive tree genetic improvement programs is the long juverile period of the olive seedlings, during which the tree does not bloom, and hence is non productive (Hackett, 1985 ).

Some authors (Garcfa-Berenguer, 1991) pointed out the need of a minimum vegetative development for young olive plants to reach the mature stage. Lavee (1990) found ways to shorten olive seedling juvcrilc period, by training single shoot upright plants together with controlled thinning and shortening lateral juvenile branches under intensive growing conditions.

On the other hand, nutritional factors, and especially nitrogen, have considerable influence on olive seedling growth in greenhouse conditions (Bartolini et al, 1984; Troncoso et al., 1986) and it seems appropriate to consider that adequate nitrogen nutrition would be of great importance in obtaining a rapid vegetative growth which would shorten the juvenile phase of olive tree. Previous studies in piants indicated that mixed nitrate-ammonium nutrition offers better results than with either nitrogen source alone (Hageman, 1984; Olsen, 1986).

In this work, the influence of the $\mathrm{N}$ form and concentration on the olive seedling growth in greenthouse conditions as well as the influence of two different substrates have been studied.

\section{Materials and methods}

Olive seedlings, cv. Manzanillo, obtained from isolated embryos germinated in vitro were used as plant material. After germination, the plantlets were transferred to $250 \mathrm{ml}$ pots with a substrate composed of perlite:sand (1:1) which were then covered with translucent plastic bags. Every 5-6 days a cut was made to the bags until the seedlings were abie to survive in the external environment. Plantlets thus obtained were used for the following experiments: 
- Exp. 1: Seedlings were transferred to 8 l. containers with inert sterile sand and treated (using a dip irrigation system) with Hoaglands, without N, 20\% solution (basa] solution) for 9 months and respectively the addition of the following $N$ concentrations and forms: Control $\left(3 \mathrm{mM}\right.$ of $\mathrm{N}$ as $\left.\mathrm{Ca}\left(\mathrm{NO}_{3}\right)_{2}\right)$ and 3,4 or $5 \mathrm{mM}$ of $\mathrm{N}$ as $\mathrm{KNO}_{3}, \mathrm{NH}_{4} \mathrm{NO}_{3}$ and $\left(\mathrm{NH}_{4}\right)_{2} \mathrm{SO}_{4}$ salts.

- Exp. 2: The same as Exp. 1, but using a substrate composed of sand:peat (1:1).

- Exp. 3: For this experiment, the seedlings were previously grown in a sand:peat (1:1) substrate for 8 months, irrigated with Hoagland $20 \%$ solution. Afterwards, the following treatments were carried out for 11 months: Control (Hoagland 20\%) and increasing concentrations of $\mathrm{NH}_{4} \mathrm{NO}_{3}(3.5,7,14,21,28,40$ and $46 \mathrm{mM}$ of N).

For all the experiments, 3 repetitions of 10 plants per treatment were performed. Plant growth was measured, as the sum of all shoot lengths, and leaf mineral composition determined according to Pinta et al. (1973).

\section{Results and discussion}

In previous studies, Samiento ef al., 1994 had found that olive seedlings cultured in greenhouse conditions on juert sand suffered serious damage with concentrations of $N$ higher than $5 \mathrm{mM}$. Lower $\mathrm{N}$ levels did not give differences in growth irrespective of the $\mathrm{N}$ form supplied after 6 months of culture. Beside this, a nitrification process affecting the $\mathrm{N}-\mathrm{NH}_{4}$ nutritive solutions was detected, which decreased $\mathrm{NH}_{4}$ concentrations while $\mathrm{NO}_{3}$ levels increased, thus changing the $\mathrm{NH}_{4} / \mathrm{NO}_{3}$ balance. This fact could be responsible for the lack of differences observed in growih.

In the present work the nutritive solutions were frequently renewed to avoid the negative effect of $\mathrm{NH}_{4}$ oxidation. With this modification, the results from experiment 1 (figure 1) regarding growth showed a clear difference among treatments. Thus, $\mathrm{KNO}_{3}$ applications did not improve the growth obtained with the control treatment at any of the concentrations tested, while $\mathrm{N}-\mathrm{NH}_{4}$ treatments resulted in significantly higher growth than that obtained with both the control and $\mathrm{KNO}_{3}$ applications, although no differences could be observed between $\mathrm{NH}_{4} \mathrm{NO}_{3}$ and $\left(\mathrm{NH}_{4}\right)_{2} \mathrm{SO}_{4}$ applications. Therefore, the ammonium application favoured olive seedling growth which is consistent with other results (Therios and Sakellariadis, 1988).

Despite the differences in growth, leaf mineral composition did not show clear variations among treatments (table 1). Nevertheless, it is worth mentioning that the highest $P$ levels wefe found in leaves of plants treated with the $\mathrm{N}_{-} \mathrm{NH}_{4}$ solutions. A similar observation was reported by Therios and Sakellariadis (1988) for the cv. Chondrolia Chalkidikis, where ammonjum nutrition favoured $P$ assimilation. On the other hand, leaves of plants treated with control and $\mathrm{KNO}_{3}$ presented higher $\mathrm{K}$ content. This fact had already been found in our previous works with in vitro cultured embryos (Sarmiento et al, 1994) and, as reported elsewhere (Kirkby and Mengel, 1967; Horst et al., 1985), may be related to competence between $\mathrm{NH}_{4}{ }^{+}$and $\mathrm{K}^{*}$ ions to enter the celts. The $\left(\mathrm{NH}_{4}\right)_{2} \mathrm{SO}_{4}$ applications gave slightly higher $\mathrm{S}$ contents in leaves.

The use of sterile sand offered the advantage of a high sensitivity to small variations in supplied $\mathrm{N}$, especially when the effect of ammonjum oxidation to nitrate was avoided. On the contrary, it did not allow the use of high $\mathrm{N}$ concentrations, which established a nartow range between deficicncy and toxicity of $\mathrm{N}$. The results obtaincd from exp. 2 (same as exp. I but changing the substrate) (figure 2), showed a higher mean growth compared to exp. 1. There were no differences in growth regardless the $\mathbf{N}$ concentration and form applied, probably because of the presence of peat in the substrate which improved the growth of seedlings treated with $\mathrm{KNO}_{3}$.

The restults of Exp. 3 are shown in figure 3. As recorded in exp. 2, the lowest concentrations of $\mathrm{N}(3.5$ and 7$)$ did not improve growth compared to control but increasing the concentration of $\mathrm{N}$ as $\mathrm{NH}_{4} \mathrm{NO}_{3}$, produced a significantly higher growth. 
Therefore, the presence of peat allowed higher applications of $\mathrm{N}\left(\mathrm{NH}_{4} \mathrm{NO}_{3}\right)$ and thus the best results in growth were achieved at $14-28 \mathrm{mM}$. Higher levels than these showed a toxic effect on seedlings, which grew less than with the control treatment.

\section{Acknowledgement}

This research was supported by Comisión Interministerial de Ciencia y Tecnología, project AGF 94-1071-CO5-04.

\section{$\underline{\text { References }}$}

Bartolini, G., Valentini, A. and Troncoso, A. 1984. Ecceso e carenza di azoto in giovani piante di olivo allevate in idroponica. Ort. Ital. 68: 169-180.

García-Berenguer, A. 1991. Respuestas morfogenéticas in vitro de la especie Olea europea L. en relación con el estado fisiológico del matcrial vegetal empleado. Tesis Doctoral, Univ. Córdoba. Spain.

Hackett, W.P. 1985. Juvenility, Maturation and Rejuvenation in Woody Plants. Hortic. Reviews 7: 109-156.

Hageman, R.H. 1984. A mmonium versus nitrate nutrition of higher plants. In: Nitrogen in Crop Production, R.D. Hauck (Ed.), Am. Soc. Agron. Madison W1, 67-85.

Horst, G.L., Fenn, L.B. and Dunning, N.B. 1985. Bermudagrass turf responses to nitrogen sources. J. Am. Soc. Hortic. Sci. 110: 759-761.

Kirkby, E.A. and Mengel, K. 1967. Ionic balance in different tissues of the tomato plant in relation to nitrate, urea or ammonium nutrition. Plant Physiol. 42: 6-14.

Lavee, S. 1990. Aims, methods and advances in breeding of new olive (Olea europaea L.) cultivars. Acta Hortic. 286: 23-36.

Olsen, S.R. 1986. The role of organic matter and ammonium in producing bigh corn yields. In: The Role of Organic Matter in Modern Agriculture, Y. Chen and Y. Avnimelech (Eds.), Martinus Nijhoff Publishers, 29-54,

Pinta and C.I.I.M. 1973. Méthodes de référence pour la détermination des éléments minéraux dans les végétaux. Oléagineux 24: 497-504.

Sarmiento, R., García, J.L., Mazuelos, C., Liñán, J. And Troncoso, A. 1994. Effect of the form and concentration of $\mathrm{N}$ on the growth and mineral composition of olive seedlings. Acta Hortic. 356: 156-161.

Therios, I.N. and Sakellariadis, S.D. 1988. Effects of nitrogen form on growth and mineral composition of olive plants (Olea europaea L.). Scientia Hortic. 35: 167-177.

Troncoso, A., Cerdá, A., and Bartolini, G. 1986. Acción del nitrógeno sobre el desarrollo y la composición mineral de plantas de olivo. Olea 16-17: 161-163. 


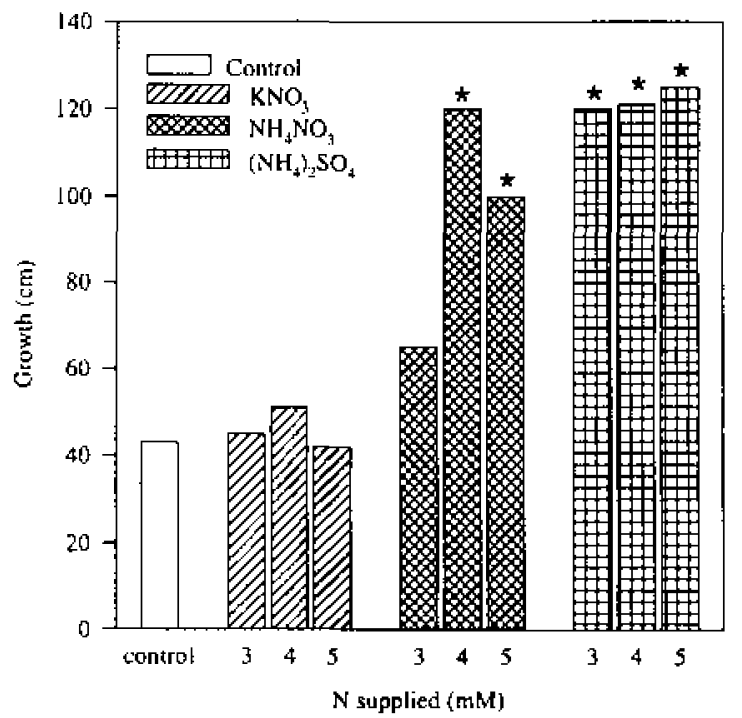

Figure 1. Olive seedlings growth on sterile sand cultured for 9 months, after the addition of different concentrations and forms of $\mathrm{N}$ (Exp. 1). The asterisk indicates statistical significance with reference to the control.

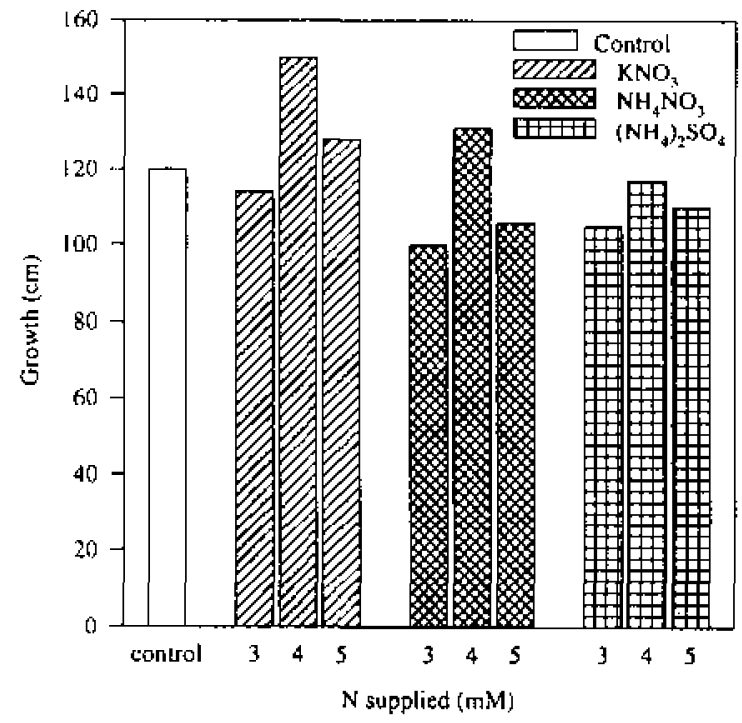

Figure 2. Olive seedlings growth on sand:peat substrate (1:1) cultured for 9 months, after the addition of different concentrations and forms of $N$ (Exp. 2). 


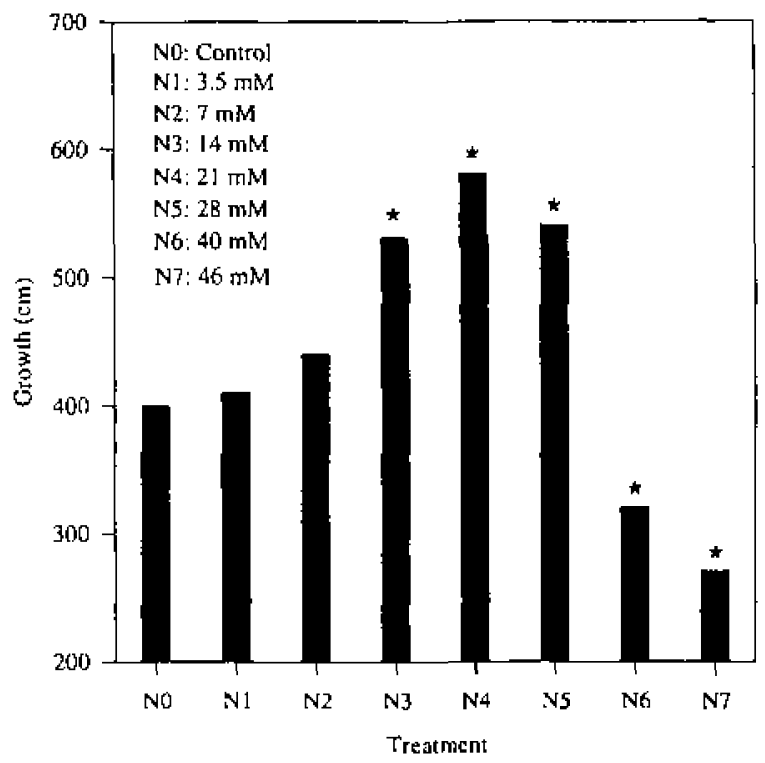

Figure 3. Olive seedlings growth on sand:peat substrate (1:1) cultured for 11 months, after the addition of different concentrations of $\mathrm{NH}_{4} \mathrm{NO}_{3}$ (Exp. 3). The asterisk indicates statistical significance with reference to the control

Table 1. Mineral composition of olive seedlings leaves cultured for 9 months on sterile sand substratc, after the addition of different concentrations and forms of $\mathrm{N}$.

\begin{tabular}{|c|c|c|c|c|c|c|c|c|c|c|c|c|}
\hline \multirow[b]{2}{*}{$\mathrm{mM}$ of $\mathrm{N}$} & & \multicolumn{7}{|c|}{$\% \mathrm{D} . \overline{\mathrm{W}}$} & \multicolumn{4}{|c|}{$\mathrm{ppm}$} \\
\hline & & $\mathrm{N}$ & $\overline{\mathrm{P}}$ & K & $\mathrm{Ca}$ & $\mathrm{Mg}$ & $\mathrm{Na}$ & $S$ & $\overline{\mathrm{Fe}}$ & $\mathrm{Mn}$ & $\mathrm{Zn}$ & $\mathrm{Cu}$ \\
\hline \multirow[t]{2}{*}{ Control } & 3 & 2.11 & 0.10 & 2.15 & 0.90 & 0.22 & 1.16 & 0.28 & 50 & 11 & 42 & 17 \\
\hline & 3 & 2.39 & 0.09 & 1.85 & 0.81 & 0.18 & 0.38 & 0.17 & $1 \overline{14}$ & 12 & $\overline{13}$ & 8 \\
\hline \multirow[t]{2}{*}{$\mathrm{KNO}_{3}$} & 4 & 2.21 & 0.09 & 2.06 & 0.71 & 0.12 & 0.22 & 0.19 & 116 & 21 & 14 & 7 \\
\hline & 5 & 2.11 & 0.08 & 2.26 & 1.10 & $0.2 !$ & 0.70 & 0.15 & 111 & 33 & 44 & 8 \\
\hline \multirow{3}{*}{$\mathrm{NH}_{4} \mathrm{NO}_{3}$} & 3 & 2.19 & 0.16 & $1.3 \overline{6}$ & 0.82 & 0.21 & $\overline{0.47}$ & 0.17 & 102 & 31 & $\overline{42}$ & 10 \\
\hline & 4 & 2.19 & 0.20 & 1.29 & 1.02 & 0.25 & 0.20 & 0.18 & 145 & 53 & 128 & 8 \\
\hline & 5 & 2.30 & 0.23 & 1.28 & 1.00 & 0.29 & 0.22 & 0.16 & 114 & 48 & 114 & 9 \\
\hline \multirow{3}{*}{$\left(\mathrm{NH}_{4}\right)_{2} \mathrm{SO}_{4}$} & 3 & 2.16 & 0.23 & 1.07 & 1.16 & 0.31 & 0.26 & 0.28 & 104 & 22 & 21 & 8 \\
\hline & 4 & 2.31 & 0.27 & 1.13 & 0.90 & 0.27 & 0.39 & 0.24 & 106 & 23 & 19 & 10 \\
\hline & 5 & 2.66 & 0.25 & 1.25 & 1.05 & 0.31 & 0.25 & 0.28 & 122 & 29 & 23 & 8 \\
\hline
\end{tabular}

